\title{
Pengaruh Pemberian Mikroorganisme Lokal Keong Mas Pengganti Pupuk Anorganik pada Tanaman Kedelai
}

\author{
N. Kurniawan ${ }^{1}$, A. P.Lestari. ${ }^{2 *}$, D. Martino ${ }^{3}$ \\ ${ }^{1}$ Mahasiswa Program Studi Agroekoteknologi Fakultas Pertanian Univeristas Jambi \\ ${ }^{2,}{ }^{3}$ Dosen Program Studi Agroekoteknologi Fakultas Pertanian Univeristas Jambi \\ *email: naning_unja@yahoo.co.id
}

\begin{abstract}
Abstrak
Penelitian bertujuan untuk mengetahui apakah Mikroorganisme Lokal Keong Mas mampu menggantikan peran pupuk anorganik pada tanaman kedelai. Pelaksanaan penelitian di "Teaching and Research Farm" Fakultas Pertanian Universitas Jambi, Desa Mendalo Indah, Kecamatan Jambi Luar Kota, Kabupaten Muaro Jambi. Rancangan yang digunakan adalah Rancangan Acak Kelompok yang terdiri dari perlakuan kombinasi pupuk anorganik N,P,K dan MOL Keong Mas, yaitu $K_{0}=100 \%$ pupuk anorganik, $K_{1}=$ 75\% pupuk anorganik dan 25\% MOL Keong Mas, $K_{2}=50 \%$ pupuk anorganik dan 50\% MOL Keong Mas, $K_{3}$ $=25 \%$ pupuk anorganik dan 75\% MOL Keong Mas, $K_{4}=100 \%$ MOL Keong Mas. Hasil penelitian menunjukkan bahwa pemberian kombinasi 50\% pupuk anorganik dan 50\% MOL Keong Mas memberikan hasil yang dapat menggantikan peran pupuk anorganik pada tanaman kedelai dan dapat mempertahankan hasil pada tanaman kedelai (Glycine max L.)
\end{abstract}

Kata Kunci: Kedelai; Pupuk Anorganik; Mikroorganisme Lokal; MOL Keong Mas.

\section{PENDAHULUAN}

Tanaman Kedelai (Glycine max L.) merupakan tanaman pangan yang termasuk dalam 3 tanaman pangan utama di Indonesia selain tanaman padi dan jagung. Tanaman kedelai yang bernilai ekonomi tinggi adalah biji polongnya. Hasil tanaman kedelai biasanya dimanfaatkan untuk pembuatan makanan seperti tahu, tempe serta kecap. Komoditas ini kaya akan protein nabati yang diperlukan untuk meningkatkan gizi masyarakat, aman dikonsumsi dan harga yang murah.

Kebutuhan kedelai sendiri terus mengalami peningkatan seiring dengan meningkatnya jumlah penduduk. Kebutuhan kedelai Indonesia setiap tahunnya \pm 2.200 .000 ton biji kering (Kementerian Pertanian, 2016). Sedangkan dilihat dari Tabel 1 produksi tanaman kedelai dalam negeri sendiri tahun 2016 hanya sebesar 859.653 ton atau $37,38 \%$ dari kebutuhan kedelai Nasional, sehingga untuk memenuhi kebutuhannya tersebut Indonesia mengimpor kedelai dari Amerika, Kanada dan Malaysia (Detik, 2017). Pupuk yang banyak dijual dan digunakan oleh petani saat ini adalah pupuk anorganik atau pupuk yang dibuat dari bahan kimia. Pupuk anorganik ini memang dapat menyediakan unsur hara yang cukup bagi tanaman. Tetapi secara perlahan membuat sifat fisik dan kualitas tanah menjadi menurun serta berdampak pada kerusakan struktur dan biologi tanah. Selain berdampak pada tanah dan lingkungan sekitar. Pupuk anorganik juga berpengaruh pada hasil yang terlalu banyak mengandung bahan kimia dan tidak sehat.

Menurut Nuro et al. (2016), permasalahan yang sering dihadapi oleh para petani kedelai adalah penurunan kesuburan tanah akibat penggunaan pupuk anorganik secara terus menerus. Oleh sebab itu, sangat diperlukan metode alternatif untuk perbaikan sifat tanah, yaitu menggunakan pupuk organik. Pemberian pupuk organik kedalam tanah dapat memperbaiki struktur tanah menjadikan tanah lebih gembur, sehingga sistem perakaran dapat berkembang lebih baik dan proses penyerapan unsur hara berjalan lebih optimal (Sri dan Tamtomo, 2016).

Pupuk organik adalah pupuk yang berasal dari sisa-sisa tanaman, hewan dan manusia seperti pupuk kandang, guano, kascing, pupuk hijau dan kompos. Pemberian pupuk organik terutama ditujukan untuk perbaikan sifat fisik tanah seperti memperbaiki struktur tanah, meningkatkan kandungan lengas tanah, menyeimbangkan pori-pori tanah dan meningkatkan ketahanan terhadap erosi (Ma'shum, 2008). 
Pupuk organik secara fisik terdapat dua jenis yaitu pupuk organik padat dan pupuk organik cair. Pupuk organik cair ada beberapa macam misalnya bio urine dan MOL atau mikroorganisme lokal, yang memiliki kandungan yang cukup tinggi dan diberikan secara langsung pada tanaman melalui mulut daun atau stomata.

Mikroorganisme lokal (MOL) keong emas dapat dijadikan sebagai pupuk cair organik yang sangat bermanfaat untuk tanaman sebab pupuk cair lebih mudah dimanfaatkan oleh tanaman karena unsur -unsur di dalamnya mudah terurai dan lengkap sehingga manfaatnya lebih mudah terasa. Sedangkan menurut Yuliani (2016) bahwa pemberian MOL keong emas sebanyak $300 \mathrm{ml}$. Baik pada parameter tinggi tanaman dengan hasil rata-rata tinggi tanaman $50,7 \mathrm{~cm}$, kemudian parameter jumlah polong total dengan hasil rata-rata jumlah polong 20,25 polong, serta parameter berat basah polong total dengan hasil rata-rata berat polong 32,01 gram pada tanaman kedelai varietas edamame

Sedangkan Soedharmo et al. (2016) mengatakan bahwa penggunaan kombinasi aplikasi 50\% pupuk $\mathrm{N}$ dengan aplikasi $50 \%$ azolla segar nyata memberikan hasil pertumbuhan tanaman yang lebih baik pada parameter panjang tanaman, luas daun dan bobot kering total tanaman dibandingkan dengan perlakuan 100\% pupuk N pada tanaman Padi. Sedangkan Suhastyo dan Setiawan (2016) mengatakan bahwa pemberian MOL bonggol pisang (penyemprotan melalui daun) dan pupuk kandang kotoran sapi dengan konsentrasi 51 ha $^{-1}$ menunjukkan hasil tertinggi pada bobot kering tanaman, jumlah polong dan jumlah biji per tanaman yang berturut - turut 103,10 g; 50,00 polong dan 72,67 buah pada tanman kedelai.

Penelitian ini bertujuan untuk mempelajari apakah Mikroorganisme Lokal (MOL) Keong Mas dapat mengantikan peran pupuk Anorganik pada tanaman kedelai dan untuk mendapatkan kombinasi Mikroorganisme Lokal (MOL) Keong Mas dengan pupuk anorganik yang memberikan pengaruh pertumbuhan serta hasil terbaik pada tanaman kedelai.

\section{METODE PENELITIAN}

\subsection{Tempat dan Waktu Penelitian}

Penelitian ini dilaksanakan di Teaching and Research Farm Fakultas Pertanian Universitas Jambi, Desa Mendalo Indah, Kecamatan Jambi Luar Kota, Kabupaten Muaro Jambi, Provinsi Jambi. Dilaksanakan selama \pm 3 bulan yakni dari 25 Juni sampai dengan 10 September 2018 .

\subsection{Bahan dan Alat}

Bahan yang digunakan pada penelitian ini adalah benih tanaman kedelai varietas Gema, tanah top soil, pupuk anorganik tunggal N, P, dan K, Mikroorganisme lokal (MOL) keong mas, dan pupuk dasar kandang ayam.

Alat yang digunakan pada penelitian ini yaitu, cangkul, parang, gembor, ember, drum, selang, penyemprot atau tabung penyemprot, jaring paranet, meteran, timbangan digital, label, gunting, patok, moisture tester dan alat tulis.

\subsection{Metode Penelitian}

Penelitian ini menggunakan Rancangan Acak Kelompok (RAK) dengan satu faktor yaitu kombinasi pupuk anorganik dengan Mikroorganisme Lokal (MOL) Keong Mas, yang terdiri dari:

$\mathrm{k}_{0}: 100 \%$ pupuk anorganik

$\mathrm{k}_{1}: 75 \%$ pupuk anorganik dan 25\% MOL Keong mas

$\mathrm{k}_{2}: 50 \%$ pupuk anorganik dan 50\% MOL Keong mas

$\mathrm{k}_{3}: 25 \%$ pupuk anorganik dan $75 \%$ MOL Keong mas

$\mathrm{k}_{4}: 100 \%$ MOL Keong mas

Setiap perlakuan diulang sebanyak 5 kali sehingga mendapatkan 25 petakan perlakuan dengan setiap petakan terdapat 90 tanaman dan setiap petakan diambil 8 tanaman sampel. Sampel diambil secara acak didalam petak ubinan.

Persiapan lahan dilakukan dengan cara mengolah tanah dengan menggunakan cangkul, dengan terlebih dahulu membuang atau mencabut gulma yang terdapat di lahan. Dilanjutkan dengan pembuatan 
https://jurnal.unsulbar.ac.id/index.php/saintifik

petakan dengan luas $2,7 \mathrm{~m} \times 2 \mathrm{~m}$, jarak antar kelompok dan jarak petakan dalam kelompok yaitu $50 \mathrm{~cm}$. Kemudian diberikan pupuk dasar kandang ayam sebanyak 5 ton/ha dan dibuat pagar untuk melindungi lahan penelitian. Penanaman benih dilakukan pada 1 minggu setelah pemberian pupuk dasar kandang ayam. Benih yang digunakan adalah benih tanaman kedelai varietas Gema.

Pengaplikasian perlakuan diberikan sesuai perlakuan yang digunakan. Pada pupuk anorganik SP-36 (P) dan $\mathrm{KCl}(\mathrm{K})$ diberikan satu kali pada hari tanam sedangkan pupuk anorganik Urea $(\mathrm{N})$ diberikan dua kali. Pertama pada hari penanam dan kedua pada umur 19 hari setelah tanam (HST) masing-masing setengah dari perlakuan yang digunakan dengan metode larikan. pemberian MOL Keong Mas yaitu pada 1 minggu sekali dimulai pada 21 HST sampai pada saat tanaman mencapai umur 63 HST atau 2 minggu sebelum panen.

Sebelum disemprotkan MOL Keong Mas diencerkan terlebih dahulu dengan perbandingan $1: 10$ untuk mendapatkan konsentrasi anjuran MOL. Penyemprotan MOL dibagi sebanyak kebutuhan perlakuan yang digunakan. Metode penyemprotan dilakukan dari bagian bawah tanaman hingga keatas tanaman atau mulai dari bagian bawah daun hingga batang sampai jatuh ke tanah dan basah. Waktu penyemprotan MOL mulai dari jam $6-10$ pagi. Varibel pengamatan penelitian meliputi tinggi tanaman, jumlah cabang per tanaman, jumlah polong per tanaman, bobot biji per tanaman, bobot 100 biji dan hasil per hektar.

\subsection{Analisis Data}

Sub bab analisis data ditulis dengan jarak spasi 1.5, huruf Times New Roman 12 pt, dan paragraph first line $1.27 \mathrm{~cm}$. Sub bab ini menjelaskan metode atau alat analisis data yang digunakan untuk interpretasi data penelitian.

Analisis data yang digunkan untuk penelitian ini menggunakan analisis ragam dan dilanjutkan dengan cara uji Duncan Multiple Range Test (DMRT) dengan taraf $\alpha=5 \%$

\section{HASIL DAN PEMBAHASAN}

\subsection{Pertumbuhan Tanaman Kedelai}

Berdasarkan hasil analisis ragam menunjukkan bahwa pemberian MOL Keong Mas dan pupuk anorganik dengan berbagai kombinasi memberikan hasil analisis yang berpengaruh tidak nyata terhadap tinggi tanaman dan jumlah cabang per tanaman, tetapi berpengaruh nyata terhadap jumlah polong per tanaman yang telah dianalisis menggunakan DMRT pada taraf $\alpha=5 \%$ dapat dilihat pada Tabel 1 .

Tabel 1. Rata-rata tinggi tanaman, jumlah cabang per tanaman dan jumlah polong per tanaman dengan berbagai kombinasi MOL Keong Mas dan pupuk anorganik

\begin{tabular}{|l|c|c|c|}
\hline \multirow{2}{*}{ MOL Keong Mas dan pupuk anorganik } & \multicolumn{3}{|c|}{ Rata-rata hasil Kedelai } \\
\cline { 2 - 4 } & $\begin{array}{c}\text { Tinggi } \\
\text { tanaman } \\
(\mathrm{cm})\end{array}$ & $\begin{array}{c}\text { Jumlah } \\
\text { cabang } \\
\text { per } \\
\text { tanaman }\end{array}$ & $\begin{array}{c}\text { Jumlah } \\
\text { polong } \\
\text { per } \\
\text { tanaman }\end{array}$ \\
\hline 100\% pupuk anorganik & $57,27 \mathrm{a}$ & $10,65 \mathrm{a}$ & $37.73 \mathrm{a}$ \\
\hline 75\% pupuk anorganik dan 25\% MOL Keong Mas & $54,72 \mathrm{a}$ & $11,05 \mathrm{a}$ & $50.95 \mathrm{~b}$ \\
\hline 50\% pupuk anorganik dan 50\% MOL Keong Mas & $55,72 \mathrm{a}$ & $10,75 \mathrm{a}$ & $45.35 \mathrm{ab}$ \\
\hline 25\% pupuk anorganik dan 75\% MOL Keong Mas & $56,82 \mathrm{a}$ & $11,55 \mathrm{a}$ & $41.30 \mathrm{a}$ \\
\hline 100\% MOL Keong Mas & $56,12 \mathrm{a}$ & $11,25 \mathrm{a}$ & $40.75 \mathrm{a}$ \\
\hline
\end{tabular}

Keterangan: Angka- angka dalam kolom yang diikuti huruf kecil yang sama menunjukkan tidak berbeda nyata menurut uji DMRT pada taraf $\alpha=5 \%$

Tabel 1 menunjukkan bahwa pemberian kombinasi pupuk anorganik dan MOL Keong Mas memberikan hasil analisis yang berpengaruh tidak nyata terhadap tinggi tanaman dan jumlah cabang per 
tanaman. Pada $100 \%$ pupuk anorganik walaupun dikurangi penggunaannya sebesar $50 \%$ dan digantikan $50 \%$ MOL Keong Mas tidak mengalami penurunan tinggi dan jumlah cabang per tanaman. Bahkan ketika digantikan sebesar 100\% MOL Keong Mas tetap tidak mengalami penurunan tinggi dan jumlah cabang per tanaman.

Namun pada pemberian kombinasi pupuk anorganik dan MOL Keong Mas memberikan hasil analisis yang berpengaruh nyata terhadap jumlah polong per tanaman. Pada 100\% pupuk anorganik ketika digantikan sebesar $100 \%$ MOL Keong Mas tidak mengalami penurunan jumlah polong per tanaman. Tetapi ketika digantikan dengan 25\% MOL Keong Mas dan 75\% pupuk anorganik berbeda nyata jika dibandingkan dengan $100 \%$ pupuk anorganik dan mengalami peningkatan jumlah polong per tanaman.

\subsection{Hasil Tanaman Kedelai}

Berdasarkan hasil analisis ragam menunjukkan bahwa pemberian MOL Keong Mas dan pupuk anorganik dengan berbagai kombinasi memberikan hasil analisis yang berpengaruh tidak nyata terhadap bobot biji per tanaman, tetapi berpengaruh nyata terhadap bobot 100 biji dan hasil per hektar yang telah dianalisis menggunakan DMRT pada taraf $\alpha=5 \%$ dapat dilihat pada Tabel 2 .

Tabel 2. Rata-rata bobot biji per tanaman, bobot 100 biji dan hasil per hektar dengan berbagai kombinasi MOL Keong Mas dan pupuk anorganik

\begin{tabular}{|l|c|c|c|}
\hline \multirow{2}{*}{ MOL Keong Mas dan pupuk anorganik } & \multicolumn{3}{|c|}{ Rata-rata hasil Kedelai } \\
\cline { 2 - 4 } & $\begin{array}{c}\text { Bobot biji } \\
\text { per } \\
\text { tanaman } \\
\text { (gram) }\end{array}$ & $\begin{array}{c}\text { Bobot 100 } \\
\text { biji } \\
\text { (gram) }\end{array}$ & $\begin{array}{c}\text { Hasil per } \\
\text { hektar } \\
\text { (ton) }\end{array}$ \\
\hline 100\% pupuk anorganik & $4,90 \mathrm{a}$ & $12,07 \mathrm{~b}$ & $2,88 \mathrm{~b}$ \\
\hline 75\% pupuk anorganik dan 25\% MOL Keong Mas & $6,33 \mathrm{a}$ & $11,76 \mathrm{~b}$ & $2,00 \mathrm{ab}$ \\
\hline $50 \%$ pupuk anorganik dan 50\% MOL Keong Mas & $5,31 \mathrm{a}$ & $11,80 \mathrm{~b}$ & $2,03 \mathrm{ab}$ \\
\hline 25\% pupuk anorganik dan 75\% MOL Keong Mas & $5,32 \mathrm{a}$ & $11,09 \mathrm{ab}$ & $1,84 \mathrm{a}$ \\
\hline $100 \%$ MOL Keong Mas & $5,45 \mathrm{a}$ & $10,64 \mathrm{a}$ & $1,54 \mathrm{a}$ \\
\hline
\end{tabular}

Keterangan: Angka- angka dalam kolom yang diikuti huruf kecil yang sama menunjukkan tidak berbeda nyata menurut uji DMRT pada taraf $\alpha=5 \%$

Pada tabel 2 memperlihatkan bahwa pemberian kombinasi pupuk anorganik dan MOL Keong Mas memberikan hasil analisis yang berpengaruh tidak nyata terhadap bobot biji per tanaman. Pada 100\% pupuk anorganik yang digantikan penggunaannya dengan 100\% MOL Keong Mas tidak mengalami penurunan, begitu juga ketika digantikan dengan 25\% MOL Keong Mas dan 75\% pupuk anorganik tidak mengalami penurunan bobo biji per tanaman.

Pada bobot 100 biji dan hasil per hektar memperlihatkan hasil yang berpengaruh nyata. Pada bobot 100 biji dapat dilihat bahwa 100\% pupuk anorganik dengan kombinasi MOL Keong Mas sebesar 50\% dan pupuk anorganik sebesar 50\% memperlihatkan hasil yang sama. Namun jika yang digunakan hanya 100\% MOL Keong Mas hasil yang diperoleh pada bobot 100 biji mengalami penurunan jika dibandingkan dengan penggunaan $100 \%$ pupuk anorganik.

Tetapi jika tetap menggunakan pupuk anorganik 25\% dan MOL Keong Mas sebesar 75\% hasil yang diperolah tidak mengalami penurunan jika dibandingkan dengan penggunaan pupuk anorganik secara penuh. Pada hasil per hektar memperlihatkan bahwa penggunaan 100\% pupuk anorganik ketika digantikan dengan 50\% MOL Keong Mas dan 50\% pupuk anorganik berbeda tidak nyata. Namun ketika digantikan dengan 100\% MOL Keong Mas hasil per hektar mengalami penurunan dan berbeda nyata jika dibandingkan dengan 100\% pupuk anorganik.

\subsection{Pembahasan}


Pemberian pupuk anorganik dan MOL Keong Mas diterapkan dengan cara yang berbeda, pupuk anorganik diberikan melalui tanah sedangkan MOL Keong Mas diberikan dengan cara disemprotkan ke daun atau stomata yang terdapat pada daun tanaman kedelai. Pemberian dengan cara penyemprotan diharapkan selain berguna sebagai penyedia unsur hara juga sebagai bio pestisida yang berperan sebagai pengendali hama pada tanaman kedelai. Faktor penguapan MOL Keong Mas akibat tingginya suhu lingkungan menjadi pertimbangan dalam penyemprotan, oleh karena itu penyemprotan dilakukan saat matahari tidak sedang bersinar dengan terik yang dilakukan dari jam 6 hingga 10 pagi agar MOL Keong Mas dapat terserap daun dengan baik dan mengurangi resiko MOL Keong Mas yang menguap akibat suhu lingkungan yang tinggi.

Berdasarkan hasil penelitian menunjukkan bahwa pemberian kombinasi pupuk anorganik dan MOL Keong Mas kepada tanaman kedelai berpengaruh nyata terhadap jumlah polong pertanaman, bobot 100 biji dan hasil per hektar. Hal ini diduga karena unsur hara pada MOL Keong Mas dapat diserap secara optimal oleh tanaman. Dimana proses pemberian MOL Keong Mas diberikan melalui mulut daun atau stomata yang disemprotkan secara berkala kepada tanaman kedelai yang dapat secara langsung diserap oleh tanaman dan juga hal ini dipengaruhi oleh faktor lingkungan di daerah penelitian seperti curah hujan, suhu, kelembaban, intensitas cahaya matahari, air serta nutrisi dalam tanah dan pada hasil analisis pemberian pupuk anorganik dan MOL Keong Mas kepada tanaman kedelai tidak berpengaruh nyata terhadap tinggi tanaman, cabang tanaman dan bobot pertanaman, yang dapat diartikan bahwa pemberian MOL Keong Mas dapat berperan sebagai pengganti dari penggunaan pupuk anorganik pada tanaman kedelai

Nitrogen diketahui berfungsi sebagai pembentuk klorofil yang berperan penting pada fotosintesis. Meningkatnya jumlah klorofil ini dapat meningkatkan laju fotosintesis sehingga pertumbuhan tanaman menjadi lebih cepat dan maksimum. Hasil fotosintesis tersebut digunakan untuk pertumbuhan organorgan tanaman, dimana semakin besar organ tanaman yang terbentuk maka semakin besar kadar air yang diikat oleh tanaman. (Damayanti et al. 2018). Selain pada tanaman kedelai yang bersimbiosis dengan Rhizobium, pada MOL Keong Mas juga terdapat Azotobacter yang mampu menyediakan hara bagi tanaman dengan cara memfiksasi $\mathrm{N}$ dari udara dan memperpanjang perakaran sehingga tanaman mampu memperoleh $\mathrm{P}$ dan peran lainnya (Kardinan, 2016).

Dari berbagai parameter pengamatan menunjukkan bahwa pemberian kombinasi MOL Keong Mas dan pupuk anorganik mampu mencukupi kebutuhan unsur hara pada tanaman kedelai. Pada hasil pengamatan secara keseluruhan menunjukkan bahwa pemberian kombinasi pupuk anorganik dan MOL Keong Mas memperlihatkan hasil yang dapat menggantikan pupuk anorganik, yaitu pada kombinasi $25 \%$ pupuk anorganik dan 75\% MOL Keong Mas dan juga pada kombinasi 50\% pupuk anorganik dan 50\% MOL Keong Mas. Namun jika dilihat dari hasil yang dihasilkan bahwa pemberian 75\% pupuk anorganik dan 25\% MOL Keong Mas memiliki hasil yang rendah dan berbeda nyata ketika dibandingkan dengan $100 \%$ pupuk anorganik. Dan pada perlakuan kombinasi 50\% pupuk anorganik dan 50\% MOL Keong Mas memiliki hasil yang tidak berbeda nyata jika dilihat dari hasil yang diperolah jika dibandingkan dengan $100 \%$ pupuk anorganik. Hal ini lah yang menjadi pertimbangan 50\% pupuk anorganik dan 50\% MOL Keong Mas dapat menekan penggunaan pupuk anorganik tetapi tetap dapat mempertahankan hasil yang tinggi jika dibandingkan dengan perlakuan kombinasi pupuk anorganik dan MOL Keong Mas yang lainnya.

\section{KESIMPULAN}

Mikroorganisme Lokal (MOL) Keong Mas mampu menggantikan peran dari pupuk anorganik pada tanaman kedelai. Kombinasi pupuk anorganik dan MOL Keong Mas yang menunjukkan hasil terbaik adalah 50\% pupuk anorganik dan 50\% MOL Keong Mas dengan menunjukkan hasil yang dapat mengantikan peran $100 \%$ pupuk anorganik pada tanaman kedelai. Disarankan untuk menggunakan kombinasi $50 \%$ pupuk anorganik dan 50\% MOL Keong Mas karena dapat memperbaiki penggunaan bahan organik tanpa menurunkan hasil pada budidaya tanaman kedelai.

\section{DAFTAR PUSTAKA}


https://jurnal.unsulbar.ac.id/index.php/saintifik

Damayanti, D. P. O., Handoyo, T., Slameto. 2018. Pengaruh Ammonium (NH4+) dan Nitrat (NO3-) Terhadap Pertumbuhan dan Kandungan Minyak Atsiri Tanaman Kemangi (Ocimum basilicum) dengan Sistem Hidroponik. Jurnal Agritrop. 16 (1) : 163-175.

Detik. 2017. Dalam Sebulan RI Impor Kedelai 242 Ton, Mayoritas dari AS. https://finance.detik.com/beritaekonomi-bisnis/d-3508804/dalam-sebulan-ri-impor-kedelai-242-ton-mayoritas-dari-as [Diakses 5 April 2018]

Kardinan, A. 2016. Sistem Pertanian Organik. Intimedia. Malang

Kementerian Pertanian. 2016. Outlook Komoditas Pertanian Tanaman Pangan. Direktorat Jenderal Tanaman Pangan. Jakarta

Ma'shum, M. 2008. Kesuburan Tanah dan Pemupukan. Fakultas Pertanian Universitas Mataram

Nuro, F. D., Priadi, E. S., Mulyaningsih. 2016. Efek Pupuk Organik Terhadap Sifat Kimia Tanah Dan Produksi Kangkung Darat (Ipomoea reptans Poir.). Prosiding Seminar Nasional Hasil-Hasil PPM IPB 2016. 29 (3). 29:39.

Soedharmo, G. G., Tyasmoro, S. Y., Sebayang, H. T. 2016. Pengaruh Pemberian Pupuk Azolla dan Pupuk N pada Tanaman Padi (Oryza sativa L.) Varietas Inpari 13. Jurnal Produksi Tanaman. 4 (2) : 145-152.

Sri, R., Tamtomo, F. 2016. Efektivitas Mikro Organisme Lokal (MOL) Dalam Meningkatkan Kualitas Kompos, Produksi Dan Efisiensi Pemupukan N,P,K Pada Tanaman Ubi Jalar (Ipomoea batatas L.). Jurnal Agrosains. 13 (2) : 21-29.

Suhastyo, A. A., Setiawan, B. H. 2016. Respon Tanaman Kedelai Terhadap Pemberian Mikroorganisme Lokal (MOL) Bonggol Pisang dan Pupuk Kandang Kotoran Sapi. Media Agrosains. 2 (1) : 1-5

Yuliani. 2016. Pemanfaatan Urine Kelinci Dan Mol (Mikroorganisme Lokal) Dari Keong Emas Untuk Peningkatan Pertumbuhan Dan Hasil Tanaman Kedelai Edamame (Glycine Max L.). Jurnal Agroscience. $6(1): 6-11$ 